\title{
Occupational bioaerosol exposure in composting plants
}

\author{
D. Forestier ${ }^{1}$, P. Thoumelin ${ }^{2}$, B. Efremenko ${ }^{3} \&$ C. Arfi ${ }^{1}$ \\ ${ }^{1} R \& D$ Santé, Veolia Environnement, Paris, France \\ ${ }^{2}$ Réseau Santé Déchets, Villeurbanne, France \\ ${ }^{3}$ Direction Technique et des Investissements, Veolia Propreté, Nanterre, \\ France
}

\begin{abstract}
The worldwide waste treatment industry VEOLIA ENVIRONNEMENT carried out a bibliographical review of the occupational exposure to bioaerosols in composting plants, which is based on a literature survey conducted since 1993 by the French Health and Waste Network.

Composting is an aerobic biological waste treatment. Bioaerosol released from composting contains mesophilic and thermophilic microorganisms. Bacteria, fungi, particularly Aspergillus fumigatus, and thermophilic actinomycetes are the most frequent microorganisms detected in the ambient air of composting plants. These microorganisms are known to be allergenic agents. Viruses and parasites have never been investigated in the air of composting plants. Microorganism concentrations in the air vary with the seasons, the type of composting process and the waste composted. Maximum microorganism concentrations $\left(10^{3}-10^{5} \mathrm{cfu} / \mathrm{m}^{3}\right)$ are detected in the loading area and during waste crushing and windrows turning. Mycotoxins produced by Aspergillus fumigatus or Penicillium that are present in the ambient air of some composting plants are correlated with high concentrations of fungi spores. High concentrations of Gram negative bacteria $\left(10^{3} \mathrm{cfu} / \mathrm{m}^{3}\right)$ (Klebsiella, Proteus, Xanthomonas, Serratia...) have sometimes been detected in the ambient air of composting plants. Endotoxin concentrations in the air range from 0,3 to $5,9 \mathrm{ng} / \mathrm{m}^{3}$ depending on the season. Mean dust concentrations reached $3,1 \mathrm{mg} / \mathrm{m}^{3}$ but dust concentration peaks have been measured during some handlings. Dust, endotoxins and (1-3)- $\beta-$ D glucan concentrations are moderately correlated in one study. Therefore it could be interesting to quantify dust concentration as an indicator of bioaerosols exposure.

Considering the variability of exposure factors, additional exposure studies would be helpful to better assess the biological risk regarding specific processes and work organisation in order to optimize preventive measures towards bioaerosols occupational exposure in composting plants.

Keywords: occupational exposure, bioaerosol, composting, allergenic, workers.
\end{abstract}




\section{Introduction}

Composting is an aerobic biological waste treatment. This process leads to organic matter oxidation by microorganisms. The composting process produces water, carbon dioxide and heat. Compost is a deodorized, hygienized and stabilized amendment resulting from the composting process. Organic waste especially food waste - household, farming and public area green waste, papers, cardboards and wastewater treatment sludges can be composted. Those wastes constitute a rich substrate for microbial growth during the different steps of the composting process.

Bioaerosols may be produced in the ambient air during the composting process especially during mechanical actions like crushing or turning of the windrows. Bioaerosols are constituted of fine liquid or solid particles suspended in the air that can contain microorganisms or biological agents.

The microorganisms and their constituent present in composting facilities, potentially dangerous for health, can be classified in three categories [1]:

- Pathogenic organisms, from fecal origin, present in the waste: bacteria, viruses, parasites;

- Allergenic organisms developing during composting process or storage: thermophilic actinomycetes and fungi;

- $\quad$ Toxins and allergens produced by bacteria and fungi.

Viruses or parasites measurements have not been carried out in the air of composting plants.

VEOLIA ENVIRONNEMENT, worldwide corporate in waste management, operates several composting plants and focuses on the specific issue of workers exposure to bioerosols. VEOLIA ENVIRONNEMENT carried out a bibliographical review of the occupational exposure to bioaerosols in composting plants, which is based on a literature survey conducted since 1993 by the French Health and Waste Network.

Several reports and papers have been published on hazards and levels of emissions in composting plants. An overview of the conclusions of those works is presented in the following paragraphs.

\section{Exposure to bioaerosols of bacteria and fungi}

\subsection{Bacteria and fungi: species and levels}

Concentrations of Gram negative bacillus can reach $10^{4} \mathrm{cfu} / \mathrm{m}^{3}$ (cfu: colonyforming unit) in the air of composting plants. Enterobacteria species detected are: Klebsiella, Proteus, Xanthomonas and Serratia. Oral transmission is the usual way of contamination. After inhalation, these microorganisms can be swallowed and then reach the digestive tract [1]. In a domestic waste composting plant, microbiological analyses result in $2.810^{4} \mathrm{cfu} / \mathrm{m}^{3}$ for bacteria including $910^{3}$ $\mathrm{cfu} / \mathrm{m}^{3}$ for Gram negative bacteria (Pseudomonas, Acinetobacter, Shigella and Yersinia) [2]. Maximum recommended levels mentioned in this study are $10^{5}$ $\mathrm{cfu} / \mathrm{m}^{3}$ for bacteria, $2.510^{3} \mathrm{cfu} / \mathrm{m}^{3}$ for each pathogenic group of microorganisms, and $10^{3} \mathrm{cfu} / \mathrm{m}^{3}$ for Gram negative bacteria [2]. 
In another study, total bacteria concentrations measured in the receiving hall and in the fermentation building of two composting plants are beyond the Canadian recommended level of $10^{4} \mathrm{cfu} / \mathrm{m}^{3}$ of air [3]. However, none of the Gram negative bacteria values exceed the recommended value of $10^{3} \mathrm{cfu} / \mathrm{m}^{3}$ of air.

Mesophilic and thermophilic fungi are identified in the compost and in the air of composting facilities. Mesophilic flora concentrations vary from $10^{4}$ to $10^{7}$ $\mathrm{cfu} / \mathrm{m}^{3}$. High concentrations are observed during waste discharge, crushing and windrows turning [1]. Thermophilic flora is present at concentrations ranging from $10^{3}$ to $10^{4} \mathrm{cfu} / \mathrm{m}^{3}$. Prevalent fungi's species are Aspergillus, Cladosporium, Fusarium, Mucor, Penicillium and Rhizopus.

In a domestic waste composting plant, fungi rise to $910^{3} \mathrm{cfu} / \mathrm{m}^{3}$, mainly Aspergillus then Penicillium, Mucor and Rhizopus. Maximum recommended levels mentioned in this study are $10^{5} \mathrm{cfu} / \mathrm{m}^{3}$ for fungi and $2.510^{3} \mathrm{cfu} / \mathrm{m}^{3}$ for each pathogenic group of microorganisms [2].

Microorganisms concentrations observed in the ambient air of another composting plant in Finland are higher than the Finnish ministry of Health recommendations (fungi: $<510^{2} \mathrm{cfu} / \mathrm{m}^{3}$ in winter, $<2.510^{3} \mathrm{cfu} / \mathrm{m}^{3}$ in summer, bacteria: $<4.510^{3} \mathrm{cfu} / \mathrm{m}^{3}$, actinomycetes: $<10 \mathrm{cfu} / \mathrm{m}^{3}$ ) [4]. The isolated species are among the most allergenic (Aspergillus, Penicillium and actinomycetes).

\subsection{Bacteria and fungi levels depend on seasons and process steps}

\subsubsection{Seasonal influence}

In two composting plants in Canada [3] in summer, actinomycete concentrations reach $1.510^{4} \mathrm{cfu} / \mathrm{m}^{3}$ in one plant, the Aspergillus fumigatus, the maximum concentration measured in the fermentation building is $1.210^{4} \mathrm{cfu} / \mathrm{m}^{3}$ in the other plant. Mean values measured in these plants would be rather low in comparison with other studies. As for fungi, concentrations in one plant vary from $60 \mathrm{cfu} / \mathrm{m}^{3}$ in the sorting hall in summer to $1.44 .10^{4} \mathrm{cfu} / \mathrm{m}^{3}$ in the receiving hall in winter. The values published range from $10^{2}$ to $10^{6} \mathrm{cfu} / \mathrm{m}^{3}$.

Microorganism concentrations are 100 times lower in winter compared to summer (composting in open air windrows) [5]. Actinomycetes concentrations vary from 0 to $310^{3} \mathrm{cfu} / \mathrm{m}^{3}$. Highest concentrations $\left(1.3510^{4} \mathrm{cfu} / \mathrm{m}^{3}\right)$ are measured in August during windrows turning.

\subsubsection{Process steps influence}

In open air windrows, microorganism concentrations are very high during composting [5]. Highest concentrations are measured during crushing and windrows turning $\left(10^{3}\right.$ to $\left.10^{5} \mathrm{cfu} / \mathrm{m}^{3}\right)$ exceeding recommended values.

In a closed composting plant, fungi concentrations are comparable in the receiving hall and the fermentation hall (from $10^{2}$ to $10^{5} \mathrm{cfu} / \mathrm{m}^{3}$, geometric mean $10^{4} \mathrm{cfu} / \mathrm{m}^{3}-10$ samples by localization) [6]. The most represented strains are Penicillium (50-60\%) and Aspergillus (20-28\%). Concentrations are lower in the control room.

Mesophilic actinomycetes concentrations are higher in the receiving hall (geometric mean $10^{3} \mathrm{cfu} / \mathrm{m}^{3}$ ) than in the fermentation hall (geometric mean 6.5 $10^{2} \mathrm{cfu} / \mathrm{m}^{3}$ ) or in the control room (geometric mean $60 \mathrm{cfu} / \mathrm{m}^{3}$ ) [6]. 


\subsection{Bacteria and fungi comparisons in the waste treatment chain}

In Austria, higher Aspergillus fumigatus, total fungi and bacteria concentrations are observed in the air of a waste sorting plant (from $4.810^{3} \mathrm{cfu} / \mathrm{m}^{3}$ to $1.710^{5}$ $\mathrm{cfu} / \mathrm{m}^{3}$ ) compared to other waste treatment plants (from $1.810^{1} \mathrm{cfu} / \mathrm{m}^{3}$ to $6.510^{3}$ $\mathrm{cfu} / \mathrm{m}^{3}$ ) [7]. Samplings have been done over a period from 4 to 6 months. Bioaerosols levels for the organic waste composting plant range from $2,6.10^{3}$ to $4,5.10^{3} \mathrm{cfu} / \mathrm{m}^{3}$ for bacteria, from $1,210^{2}$ to $1,510^{2} \mathrm{cfu} / \mathrm{m}^{3}$ for Aspergillus Fumigatus and from $1,810^{3}$ to $6,510^{3} \mathrm{cfu} / \mathrm{m}^{3}$ for total fungi.

However, maximum actinomycetes levels (from $2,410^{3}$ to $7,310^{3} \mathrm{cfu} / \mathrm{m}^{3}$ ) were found in the organic waste composting plant (closed system) compared to the waste sorting plant and to the agricultural composting plant (open site).

\section{Exposure to endotoxins and mycotoxins}

\subsection{Endotoxins levels in composting plants}

Endotoxins form part (the lipopolysaccharide (LPS) complex) of the outer membrane of the cell wall of Gram-negative bacteria. A health-based exposure limit of $50 \mathrm{EU} / \mathrm{m}^{3}$ (EU: Endotoxin Unit) $\left(5 \mathrm{ng} / \mathrm{m}^{3}\right)$ has been proposed in The Netherlands in 1998 and a temporary legal limit of $200 \mathrm{EU} / \mathrm{m}^{3}$ has been implemented in 2003 [8].

Endotoxins concentrations measured in the atmosphere of composting plants vary, according to studies, from 1,7 to $55 \mathrm{ng} / \mathrm{m}^{3}[1]$.

One study compares the levels of endotoxins in different waste treatment plants [9]. Endotoxins levels measured in incinerators are close to background $\left(2 \mathrm{ng} / \mathrm{m}^{3}\right)$. In the waste sorting plants, the concentrations are 2-4 times as high as the background concentrations. According to the author, those concentrations are similar to those in composting plants.

In a composting plant in Finland, endotoxins levels are lower than $35 \mathrm{ng} / \mathrm{m}^{3}$ at all measured points (from 21 to $266 \mathrm{EU} / \mathrm{m}^{3}$ ) [4].

\subsection{Endotoxins levels depend on seasons and process steps}

In the background air of a composting plant in Finland, endotoxins ambient concentrations vary from 0,8 to $2,4 \mathrm{ng} / \mathrm{m}^{3}$ in summer and from 5,6 to $5,9 \mathrm{ng} / \mathrm{m}^{3}$ in winter [5].

Measured values increase during crushing. During windrows turning, concentrations are higher than maximum recommended levels.

In a closed composting plant in Finland, endotoxins levels are higher in the two process zones $\left(1.900 \mathrm{EU} / \mathrm{m}^{3}\right.$ in the receiving hall and $2.340 \mathrm{EU} / \mathrm{m}^{3}$ in the drum composting hall) than in the control room $\left(100 \mathrm{EU} / \mathrm{m}^{3}\right)$, this last point complies with the temporary Dutch maximum limit of $200 \mathrm{EU} / \mathrm{m}^{3}$ [6].

\subsection{Relation between endotoxins and dust levels}

In an urban sorted waste composting plant, personal exposure means values vary from 50 to $1000 \mathrm{UE} / \mathrm{m}^{3}$ for endotoxins [10]. Endotoxins geometric means 
concentrations vary from 29 to $527 \mathrm{EU} / \mathrm{m}^{3}$ for endotoxins, and from 360 to 4850 $\mathrm{ng} / \mathrm{m}^{3}$ for (1-3)- $\beta$-D glucans [11]. Static samplings results are inferior or equal to personal worker samplings.

Mean values of personal exposure to dust vary from 0,4 to $3,1 \mathrm{mg} / \mathrm{m}^{3}$ [10]. Geometric means of dust concentrations after individual sampling on workers vary from 0,3 to $1,8 \mathrm{mg} / \mathrm{m}^{3}[11]$.

Dust, endotoxins and (1-3)- $\beta-\mathrm{D}$ glucans concentrations are moderately correlated in this study.

\subsection{Mycotoxins levels in composting plants}

Mycotoxins are produced by fungi or their metabolites. Ten molecules are found in pure cultures. Seven are more frequently detected [12]. Two molecules produced in culture are found in the air of one organic waste composting plant: 2-tryptoquivaline and trypacidin. Those molecules are Aspergillus fumigatus specific and could be used as an exposure indicator. Spores concentration is high in the atmosphere of the plant where the toxins were found, $\left(3.2 .10^{7} \mathrm{ufc} / \mathrm{m}^{3}\right)$ but dust concentration is low $\left(0.682 \mathrm{mg} / \mathrm{m}^{3}\right)$. Opposite situation is observed in the other plant: 0 toxin, spores; $1.510^{6} \mathrm{ufc} / \mathrm{m}^{3}$, dust; $1.372 \mathrm{mg} / \mathrm{m}^{3}$. In these two plants, there is no correlation between dust and fungi's spores. Toxins are related to spores but not to dust concentrations (no adsorption).

\section{Discussion}

Culture-based methods have several constraints as long as they are not easily reproducible - a specific kind of germ is selected according to the medium and the conditions of culture. Moreover, dead microorganisms and their cellular residues cannot be detected.

Sampling procedures seem also limited since they are often carried out during a short time (15 to 120 minutes) while germs atmospheric concentrations vary largely during a whole day. Hence those samplings cannot show peaks of concentrations.

Cellular microorganisms quantification methods have been developed. These methods can identify dead and alive microorganisms without selecting different kinds of germs. These methods have variable sampling duration. However, they are complex, long and expensive methods for which there are usually no sanitary limit levels.

Other techniques (mass spectrometry, immunoenzymatic methods, PCR...) consist in quantifying components or metabolites of the microorganisms (mycotoxins, endotoxins), which can be markers of different kinds of microorganisms. Nevertheless these techniques are not totally available and there is no reliable biomarker of exposure as there is for exposure to chemical pollutants.

Even for well known pathogenic agents, clear dose-response relationships have not been established. This is mainly due to a lack of valid methods to assess exposure quantitatively, which makes difficult risk assessment [8]. 
Further researches are needed to improve the sampling methods for bioaerosols and to validate analytical methods. It would be interesting to investigate the potential protective effects of microbial agents and the interactions between various agents in causing health effects. Moreover, the available methods need to be standardized.

Considering variability of the exposure factors, additional exposure studies would be helpful to better assess the biological risk regarding specific processes and work organisation in order to optimize preventive measures towards bioaerosols occupational exposure in composting plants.

\section{References}

[1] Deloraine A. Etude bibliographique sur l'évaluation des risques lies aux bio-aérosols générés par le compostage des déchets. CAREPS. Rapport n³17 à l'ADEME. Mars 2002.

[2] Heida H, Bartman F, Van Der Zee SC. Occupational exposure and indoor air quality monitoring in a composting facility. Am. ind. Hyg. Assoc. J., 1995, 56, (1), 39-43.

[3] Lavoie J, Alie R. Determining the characteristics to be considered from a worker health and safety standpoint in household waste sorting and composting plants. Ann. Agric. Environ. Med., 1997b, 4, 123-128.

[4] Tolvanen OK, Viilos P, Hänninen KI, Veijanen A. Occupational hygiene at a drum composting plant in Hyvinkää, Finland. Proceedings ORBIT 99, 1999, 629-635.

[5] Tolvanen OK, Hänninen KI, Veijanen A, Villberg K. Occupational hygiene in biowaste composting. Waste Manage. Res., 1998, 16, 6, 525-540.

[6] Tolvanen O, Nykanen J, Nivukoski U, Himanen M, Veijanen A, Hanninen $\mathrm{K}$. Occupational hygiene in a Finnish drum composting plant. Waste Management, 2005, 25, 427-433.

[7] Reinthaler FF, Haas D, Feierl G, Schlacher R, Pichler-Semmelrock FP, Kock M, Wust G, Feenstra O, Marth E. Comparative investigations of airborne culturable microorganisms in selected waste treatment facilities and in neighbouring residential areas. Zent. bl. Hyg. Umweltmed, 1998/1999, 202, 1-17.

[8] Douwes J, Thorne P, Pearce N, Heederik D. Bioaerosol health effects and exposure assessment: progress and prospects. Ann. Occup. Hyg., 2003, 47 (3), 187-200.

[9] Rahkonen P. Airborne contaminants at waste treatment plants. Waste Management \& Research (1992) 10, 411-421.

[10] Douwes J, Dubbeld H, Van Zwieten L Wouters I, Doekes G, Heederik D, Steerenberg P. Work related acute and (sub-) chronic airways inflammation assessed by nasal lavage in compost workers. Ann. Agric. Environ. Med., 1997, 4, 149-151.

[11] Douwes J, Wouters I, Dubbeld H, Van Zwieten L, Steerenberg P, Doekes G, Heederik D. Upper airway inflammation assessed by nasal lavage in 
compost workers: a relation with bio-aerosol exposure. Am. J. ind. Med., 2000, 37, 459-468.

[12] Fischer G, Müller T, Ostrowski R, Dott W. Mycotoxins of Aspergillus in pure culture and in native bioaerosols from compost facilities. Chemosphere, 1999b, 38, 1745-1755. 